\title{
BRITISH EAR AND THROAT CLINICS HISTORICALLY CONSIDERED.
}

\author{
Bi RichaRD KERSHAW, \\ Secretary-Supsrintendent, Central Lomılon Throat and Ear Hospital.
}

" Wrth every increase in the workls stock of gold, the metal loses something of its value, while every adilition to the world's store of scientific truth alds to the value it already had, and is a stepping-stone to the acquisition of more." Thus spoke Sir William Jenner at the opening of the Seventh International Medical Congress held in London in 1881. With the advent of the Seventeenth Congress. which, after a periou of thirty-three years, meets again in London, it seems an appropriate occasion to give some account of the method of action, and the result arising from that action, in resard to the provision which has been made in this country for the study and the relief of clisease of the throat, nose and ear.

In this retrospect no excursion will be made into the fascinating history of antiquity, nor even into that of the far distant days when the sick were treated and housed in monastic or secular institutions, and when medical treatment was closely supervised by the priests, but it will be confined mainly to the rise and progress of otologr and larrngology in modern medical institutions for which we have our own aceurate records. The story which we have to tell clates from the beyinning of the nineteenth century, at which time we find that there were special hospitals in this country for the treatment of ere and ear disease. The constructive period of hospitals, as we know them to-day, ran hardly be said to have commenced until the middle of the century, whence began an era so full of creative conception and brilliant medical it hievement, that long before the close of the century there was witnesset in entire transformation in the hospital world, and in every arency which had for its object the relief of the sick.

If a dip be made into institutional literature it will be found that in the rear 1800 there were in Great Britain 154 hospitals and dispensaries supported entirely by voluntary contributions: 31 of these institutions were situated in London and in a very limited area; 68 were in the larrest towns of the provinces; 41 were in Ireland; 14 were in Seotland.

In this list are included sixteen dispensaries (for out-patients) situated in London and thirty-six in the provinces. Some of these dispensaries found it necessary to enlarge the seope of their work, and this was carried sut to such an extent that in the course of time and of financial affluence they developed into large general hospitals. At that time the special hospitals, which are still with us, and included in the foregoing list, were represented in London by four lying-in hospitals, two for the mentally afflicted, one for smallpox, and one lock hospital. Here and there in the provinces and in Ireland were to be found special institutions for the treatment of eve and ear disease, whilst the lring-in hospitals were for the most part attached to, or under the control of, religious communities. Many charitable agencies were also in existence to provide for the spiritual and educational welfare of the blind, and the teaf and dumb.

Behind us lies a century of hospital work; where do we now stand? Long before the dawn of the twentieth century we find that our previous list of medical institutions had increased from 154 in 1800 to over 1100 
in 1900. Moreover, in this number are not included the hundreds of cottage hospitals which are now to be found in the outlying districts of our large cities and towns, neither has any account been taken of the numerous public and provident lispensaries-such important links of the hospital system-abounding in all parts for the treatment of outpatients.

In the first half of the century, that is from 1800 to 1850,293 hospital. were founded, 46 of them heing purely special hospitals, while in the last half of the century orer 800 came into existence, 123 being special hospitals. The greatest and most noticeahle increase took place in the decade of $1870-1880$, when 166 hospitals were founded, 30 of them being special, of which 11 were for the treatment of the eve, ear, and throat.

It may well be asked what influence created this outhurst of metical activity : It cannot he doulted that the most powerful of all factors. leading to hospital extension, was the visorous growth of specialism brought about by the natural division of labour, as necessary in the practice of medicine as in the inhustry of commerce. When alluding to specialism in relation to medicine. Sir James Paget remarked. in his inaugural address at the Serenth International Medical Conpress: "It cammot be said that in any of our sections there is not enough fore at full strong mind to do. It anyone will donbt this, let him try his own strength in the discussion of sereral of them."

The institutions in which we are naturally most interested are thent haring for their object the sturly and the treatment of diseases of the throat, nose and ear, and we sive a list of them in chronologrical oreler together with the names of the founders.

We do this for the purpose of showing the persistent enterprine of our predecessors, and to remind ourselves of those pionecre to whose real we owe so much and whose memory we lelight to honour. It must not he forgotten that these men laboured under difficulties ant oppression the like of which we hare never experienced, so that our progres hat been mate under conditions of luxurious comfort in comparison witl: theirs.

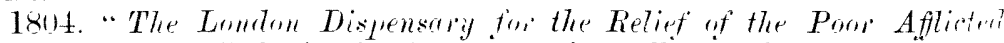
with Eye Liserse." the institution now universally familiar hy the name of " Moorfiekls," foumded hy Dr. Cumningham Sa unders, an aural surgeon as well as a distinguished omlist of his day. It is recorded that In. Saunlers treated disease of the ear as well as the ere in this institution. which is not surprising seeing that he was one of the earliest British writers on subjects pertaining to the ear.

1814. "Driblin Ege and Ear Hospital," founderl hy Surweon Rvill under the title of the "National Ere and Ear Hospital." To thi institution came Sir William Wilde, who founded St. Mark s Ophthalmir Hospital in 1844. buth institutions eventually heing merged inte the "Roval Victoria Eye and Ear Hospital." 'The original institution appears to have been at that time the only one of its kind in Great Britain where chinical and practical instruction in aural surgery was giren to students, and if this version be correct, Sir William "Wilde must be regarded as the earliest systematic teacher of aural surgery in thin country.

1816. "The Roryal Ear Hospitul," London, founded by Dr. Harrison Curtis under the title of the "Dispensary for Diseases of the Ear." From its earliest dars this institution has beein situated in the vicinity of Dean Street, Soho, and has been faroured with hoyal patronage throughout itcareer. 
1818. "Stherstring Eye, Ear and Throut Hospital," founded br In. G. F. D. Evans as an ophthahnic institution: treatment of cliseases of the ear ander the same roof som followed, and eventually that of the timroat, hence its present title.

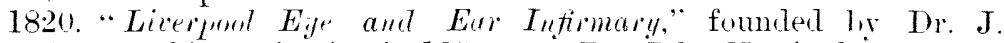
O'Neill. To this institution in 1850 came Dr. John Nottingham, whose work on "Diseases of the Ear" was puhlished in 1857.

18.21. "Leeds Eye and Eur Disprestry." This institution during its career had a very large out-patient department, and six beds for inpatients. Mr. Thomas Nunnely was Surqeon from 18:55 to 1864. In lstia the institution amalgamated with the General Infirmary.

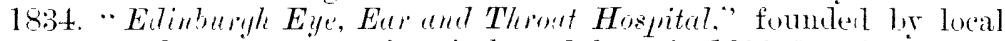
protitioners first as an eye hospital, and later in 1883 for the further whjects indicated by its present title.

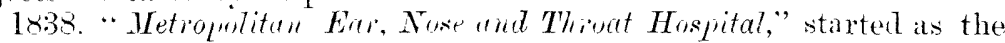
" Ear Infirmary and Urthophonic Institution." Associated with this hospital in its early career was James Tearsler, who was followed by Finnes Hinton and Peter Allen, the former leaving to take charge of the Aural Department at Guy s Hospital in 1863, and the latter to succeed Tornbee at St. Mary in 1868 .

1844. "The Birminglam Institution for the relief of Deafness and Dineases of the Ear" was founded mainly through the enterprise of Dr. I hutton, who in the same rear published a work entitled " The Nature and 'Treatment of Jeafness and Diseases of the Ear and of the Treatment of the Deaf and Dumbl," This institution amalganater in 1871 with the Bimmingham Eye aml Ear Hospital, and erentually the title hecames hamgerl to the Brmingham and Milland Ear and Throat Hospital. Attailhed to this institution was Ir. Charles Warden, so well known to our hiler hospital staffs.

184t. " Brelfust Ele and Ear Hesjitul," founded as a dispensary by 1)r. Samuel Browne, surgeon to the General Hospital in that city. His (m), J)r. Walton Browne, is at the present time the Senior Surgeon of this muth enlarged hospital.

184t. "Dublin st. Murlis Oplthulmir Hospitul." fomded by Sin Wiliam Wille, for the treatment of ere and ear disease. This institution was eventually mersed into the hosital previonsly alluded to as the Rọal Victoria Eve and Ear Hospital.

1847. "Kent Cosinty Oplethelmie Hospital." Maridstone, founderl ly Lord Rommey, the first President, and Mr. John Woolcott. F.R.C.S., the tist Honorary Surgeon. Six years after the foundation of this hospital, it was agreed by the managers to treat ear lisease as well as eye disease, hut the first defined appointment of aural surpeon appears to be as inent as 19019 , since which date has arisen a latge ear and throat clinic.

1855. "Manchester" Eur' Hespital."

1857. "Brolford Eyr and Ear Hospital," foumled by Dr. Edward Bromer, whose son. Dr. Adolph Bronner, is now the Senior. Surgeon at the ame institution.

1861. "Glasgon Ear. Nose and Throut Hospital," fommler in Dr. Paterson Cassells, one of the two Vice-presidents of the Section of Otologry at the International Medical Congress of 1881 ; at a later late he wis "ppointed aural surgeon to the Glasgow Royal Infirmary.

1363. "Corl O Opthalmir Hospital," now known as the Cork Eve, Ear and Throat Hospital, founded by Dr. Macnaughton Jones, who also fommled the Hospital for Women and Children in the same city.

1863. "The Hospital for Dizenses of the Throut," Londun. founded 
by Sir Morell Mackenzie, the first President of the original Laryngological Association, and the founder in 1887 with Dr. Norris Wolfenden of this Journal.

1871. "Belfast Eye, Ear and Throat Hospital," founded by Dr. W. A McKeown.

1874. "Central London Throat and Ear Hospital," foundel by Mr. Lemnox Browne.

1875. "Manchester Hospital for Consumption and Throat Disease," founded by Dr. Hodglinson and Dr. Fletcher.

1877. "Dub?in Throat and Ear Hospital."

1878. "Brighton Throat and Ear Hospital," founded mainly through the energy of Dr. Cresswell Baber and Dr. Scatliff.

1878. "Tunbridye Wells Eye and Ear Hospital."

1s78. "Nemeastle Throat and Ear Hospita?," founded by Dr. Richard Ellis.

1881. "Londonderry Eye, Ear und Throat Hospital," founded by Drs.

Donaldson, Bernard and Hunter.

1882. "Hereford Eye and Ear Hospital."

1884. "Portsmouth Eye and Ear Hospital," with the foundation of which Dr. Ward Cousins was so closely identified.

1886. "Hulifar Eye and Ear Hospital," founded by Dr. Oakler.

1887. "London Throat Hospital," founded by Drs. Edward Woakes, MacNeil Whistler, George Stoker and others.

1888. "IIanchester Eye and Ear Hospital," founded by Di. David McKeown.

1889. "Cheltenham Eye, Ear and Throat Hospital."

It is interesting to note how frequently institutions started primarily for the treatment of diseases of the eve extended their sphere of action to the ear and throat. Only in one instance can we recall an old institution founded, and continued up to this day, for the purpose of treating the ear alone, but even in this institution simultaneous treatment of the nose and throat with that of the ear has been necessarily called for. In this day, when one hears so much of co-ordination and consolidation of medical work, the often-repeated suggestion as to the advantage of treating the eye, ear, throat and nose under one roof seems to be worthy of more than passing consideration.

Before taking leive of the special hospitals, some reference must be made to the educational side of their work, and if the following figures prove anything at all, they forcibly prove that these institutions-the pioneers of post-graduate teaching in this country-have been eminently successful as medical schools for special subjects. Have not the ophthalmic and the aural surgeons, and the laryngologists at the general hospitals, qualified for those positions in the special hospitals?

From records available for 1912, we find that 924 students enrolled themselves, for periods of three months and upwards, at twenty Metropulitan special hospitals, including those for the eye, ear and throat, skin, paralysis, women, consumption and cancer, whilst the number of medical practitioners attending, in a casual way, at these particular hospitals to witness the practice of the medical staff amounted to over 2000 .

At two of the Throat and Ear Hospitals in London where special provision is made for systematic instruction the number of post-gra luate students in 1912 was close upon a hundred, and the number of practitioners attending the lectures and the clinics from time to time was upwards of a thousand.

Here, then, is a rough outline of the activity of our specialism as 
exemplified hy the establishment of special hospitals. The remarkable progress made by these institutions brings with it a feeling of astonish. ment that there should have been at any time an attempt to arrest their wrowth and development.

Great as has been the activity within these institutions, greater still hats been the apathy towarts the establishment of special departments in the seeneral hospitals. The cause of this apathy is, however, an old story familiar to all of us, and we like to think that it is now buried in the atbinet of medical ariosities. Let us therefore dwell on the more agreeahle and the useful aspect of our specialty, resting content with the ummistakable testimonr that every special department established in a seneral hospital is a tribute to special hospitals.

The earliest special aural department at a general hospital appears to he that of St. Mary's Hospital, London. It was inaugurated in 1851 , six years after the foumiation of the hospital itself. This department was placed in charge of Joseph Turnbee, F.R.S , whose work on "Diseases "f the Ear" was deticated "To" the Governors who, by establishing" atural suruery as a distinct department of study in their hospital and medical school, evinced a desire to elevate the sulject of diseases of the ear to its due position, as a hranch of professional knowledge, hased npun clinical olserration and scientific resedrch."

In 1844, at St. Mark's Ophthalmic Huspital, Dublin-a purely special hespital-sir William Wilde had an aural department, and there he atopted a srstematic method of instruction to students. It is reasonable to suggest that the influence of the teaching of these two distinguished recialists was the starting-point of special departments, but the utablishment of these lepartments was a slow process. There was llways a prejulice on the part of the leaters of the medical profession ratinst specialism, a prejulice which, fortunately, was mirthfully wnored by those who were fast breaking atray from the crystallised intholoxr of the serlate seneral hospitals.

Another element which delayed the progress of the specialty was the thet that aural surgery and laryngology, unlike ophthalmic surgery, formed little or no part of the student s curriculum, and a still smaller fart of any "qualifying examination: its stutr, therefore, was deplorably Anlected. Is it, then, to be womlered at that the late Sir Henry Butlin. Presilent of the Roval College of Surgeons, explaining the position if larrnuology and otology when he entered the profession, should have plike il on recoml the statement that -... The special depurtments in the sispitals were officeret hy men who were too often very ignorant of their - precialties, and there were specialists who really knew their work, but were carefully exciuted from the peneral hospitals."

Here and there are to be found isolated instances of an ere and ear leprartment of earlier dates than those we have just mentioned ; such, for ximple. is that of the Roral City of Dublin Hospital, which establisherl, at the time of its foundation in $183^{\circ}$, special dispensaries for the re and ear.

This combination of the eye and ear in one department has been coninted down to the present time, and is an imitation of the procedure nopted by the earlier special hospitals which combined the ere and ear umler one roof and freiquently miler the single title of "ere hospital." This combination is, in some districts, still in force, particularly in Ireland. The Kent County Ophthalmia Hospital has increasel its scope ly ahmitting diseases of the ear, nose and throat, hut it does not aple er iir have alded this designation to its title, in spite of the fact that in 
1912 the attendance of aural patients was nearly as great as that of the eye cases, whilst the operations upon the ear were actually greater in number than those upon the eye.

Many years, however, passed before either the eve or the ear cases were treated in separate departments having an entity of their own. ant even when separate departments were established, little or no interest was taken in them by the managers; they were badly equipped, and ther were carried on in a perfunctory kind of manner with a sort of "Box and Cox" arrangement of attendance. In this war ther crept along until the younger generation of medical officers, fresh from the special hospitals, hrought with them newer ideas and keener enthusiasm than had hitherto prevailed, so that these departments speedily hecame: recognised as not the least important part of the organisation of the hospital. A new problem now faces the managers-the necessity for additional in-patient accommodation for ear and throat cases.

The present infinitesimal allotment of beds for the ear and throat departments is ludicrous-in some cases the proportion is no more thatn one bed per thousand out-patients, whereas five beds per thousand are required. We anticipate that the next agitation will be to secure separate wards for each special department commensurate with th. importance and the amount of the work carried on.

One of the many pleasint features of the present-day hospital system is the hearty co-operation which takes place between the general and the special hospitals: nowadays it is a common practice to transfer patients from one institution to the other, and we should welcome a development of this practice. In some of the large centres this well organisel co-operation has rendered it unnecessary for the general hospital to establish a special department of its own. How much more useful is this colleagual intercourse and goodwill than the former attitucle of selfsufficiency.

Space prevents us dwelling any further on our theme, and we close it in the belief that our specialty has added something " to the world" store of scientific truth" and to the happiness of mankind.

A List of some of the Special Departments for Ear and Thout at the General Hospitals, with the Date of their Inauguration. It has bern impossible to follow the foundation of these delartments step by ste".. and therefore the list is not offered as a complete one, but it serves th. purpose of showing the progress in different parts of the Kingdom Many large General Hopitals have no Ear or Throat department on account of the near proximity of a Special Hospital to which patients are referred.

St. Mary's Hospital, London Mr. Joseph Toynbee, F.R.S., attached 1851-1864. Mr. Ernest Hart Mr. Peter Allen Mr. George Field

Guy's Hospital

Mr. James Hinton attached 1863.

St. Bartholomew's Hospital, Rochester

\begin{tabular}{|c|c|c|}
\hline $\begin{array}{l}\text { Ear } \\
\text { Depart. } \\
\text { ment. }\end{array}$ & $\begin{array}{l}\text { Throat } \\
\text { Depart- } \\
\text { ment. }\end{array}$ & \\
\hline 1851 & 1864 & $\begin{array}{l}\text { Combined as } \\
\text { Ear, Nose and } \\
\text { Throat, } 190 \mathrm{~s}\end{array}$ \\
\hline 1863 & 188.5 & $\begin{array}{c}\text { Combined } \\
1902 .\end{array}$ \\
\hline $1 \& 63$ & 1863 & Separate. \\
\hline
\end{tabular}


London Hospital

Dr. Hughlings Jackson, first Physician-in-Charge Ear lepartment, 1867.

Mr. Rivington, first Surgeon-in-Charge Ear Department, 1867 .

Mr. Reeves, Surgeon-in-Charge Ear Department, 1869.

Dr. Gardiner Brown , 1876.

Dr. Edward Woakes " " $\quad 1882$.

St. Bartholomew's Hospital, London ".
Sir Thomas Smith first Officers-in-Charge of Sir Thomas Smith
Mr. John Langton $\}$ first Officers-in-Char
Ear lepartment.

Sir Lauder Brunton f first Officers-in-Charge of

Sir Henry Butlin $\}$ Throat Department.

Leeds General Infirmary : jo beds specially allotted to the Ear Department (1912)

St. George's Hospital

Sir William Dally in charge of Eax Department.

Glasgow Royal infirmary.

Dr. Paterson Cassells in charge of Ear Department, 1887.

Dr. Steevens' Hospital, Dublin

King's College Hospital, London

Di. Urban Pritchard first Officer-in-charge of Ear Department anil Professor of Aural Sursery.

St. Thomas's Hospital

Sir Felix Semon. Physician Throat Department. $18 \times 2-1847$.

Dundee Royal Infirmary

Ear and

Throat com. bined.

Middlesex Hospital

$186(1$

1853

Edinhurgh Royal Intirmary

Chester Infirmary

1865

Mater Misericordic Hospital, Dublin

Westminster Hospital

Leicester Infirmary

Royal Infirmary, Bradford

Royal Victoria Infirmary, Newcastle

Liverpool Royal Infirmary

Liverpool Southern Hospital

Addenbrook's Hospital, Cambridge

Bristol General Hospital

sheffield Royal Hospital

Southampton Hospital

Reading Hospital

Birmingham General Hospital .

Sir Patrick Dun's Hospital, Dublin

Derby Royal Infirmary

Bristol Royal Infirmary

Radeliffe Infirmary, Oxford

Cheltenham General Hospital

18851885
1856

1890

$1891 \quad 1891$

1.93 1893

$1893 \quad 1893$

$\begin{array}{l:l}1894 & 1896\end{array}$

About 1894

,y- 1894

$1697: 1897$

1899

1900

1902

1906

1906

$1912 ! 1906$

1906

1909

Combined.

Eye and Ear combined.

Separate.

Combined.

.,

..

,

Combined in 1911.

Combined.

Separate.

Combined.

,

,

,

,

Separate.

Combined.

Eye, Ear,

Nose and

Throat

combined.

Lincoln County Hospital .

combined.
Combined. 